\title{
The effects of temperature and salinity on molting and survival of Menippe adina and M. mercenaria (Crustacea, Decapoda) postsettlement juveniles
}

\author{
Susan D. Brown, Theresa M. Bert \\ Florida Marine Research Institute, 100 8th Avenue Southeast, St. Petersburg, Florida 33701-5095, USA
}

\begin{abstract}
Comparing the effects of temperature and salinity on the survival and growth of animais in early life stages may contribute toward our understanding of the basic ecological differences between congeneric species and of the evolutionary mechanisms operating within a genus. Postsettlement juvenile crabs of the species Menippe adina and $M$. mercenaria were held in factorial arrays of temperature and salinity to determine the effects of these factors on survival and molt frequency. The patterns of the effects of temperature and salinity on both molting and survival were similar for the 2 species. Optimal conditions predicted for survival of each species were also similar, but the percentage of crabs that survived at specific treatments differed. In general, $M$. adina showed a greater tolerance to low temperature and low salinity than did $M$. mercenaria. The observed differences may be important in determining the distribution of these species in terms of both their geographical range and their distribution from nearshore to offshore. These differences may be species-specific, with some adaptation to local conditions; species-specific differences would support a theory of allopatric speciation of these Menippe species.
\end{abstract}

\section{INTRODUCTION}

The physical parameters to which a species is exposed have a significant impact on its physiology. The most common environmental factors used to test physiological response of marine organisms are temperature and salinity, and a comparison of responses to these factors can help determine if fundamental ecological differences exist between 2 congeneric species. Different responses to temperature and salinity have been found for congeneric marine species in areas such as kinetic properties of enzymes (Hochachka \& Somero 1984), energetics (Levinton 1983), oxygen compensation (Mangum 1963), and osmoregulation (Rodriguez 1981). The most basic responses that can be used to compare species are survival and growth (i.e. development). These responses may reflect or influence other aspects of biology such as distribution, reproduction, and behavior.

Studies of differences in the effects of temperature and salinity on survival and growth of animals in early life stages are especially important because animals at these stages are usually more sensitive to environmental parameters than are adults (Kinne 1970, 1971). Watts et al. (1982) found that rates of larval development differed between sibling species of Echinaster when temperature and salinity differed. Mills \& Fish (1980) determined that Corophium arenarium could not penetrate as far upstream in an estuary as $C$. volutator because $C$. arenarium juveniles were less tolerant of low salinity. Similarly, Antonopoulou \& Emson (1989) suggested that temperature and salinity tolerance limits prevent Palaemonetes longirostris larvae from inhabiting the upper parts of estuaries where $P$. varians larvae can develop. In brachyurans, the postsettlement juvenile stage represents an interesting period in the life cycle: crabs have entered the benthic habitat but have not yet developed adult tolerances to physical factors (Kinne 1970, 1971).

In the Gulf of Mexico, 2 species of stone crab occur: Menippe adina in the western portion, and $M$. mercenaria in the eastern portion. Along the coast of north- 
west Florida, the ranges of these species overlap and hybrid forms, as well as pure species, have been identified based on phenotypic and genotypic characteristics (Bert \& Harrison 1988). Throughout the range, $M$. mercenaria typically live in burrows in grass flats or in crevices among rocks and experience annual temperatures and salinities that are relatively stable (Bert et al. 1986). M. adina also live among oyster reefs and mud flats in areas where temperature and salinity fluctuate seasonally (Baltz \& Horst 1992).

Survival and development of larvae held in the laboratory at various temperature-salinity combinations have been reported for both Menippe mercenaria (Ong \& Costlow 1970, Field 1989, Brown et al. 1992) and $M$. adina (Field 1989). In comparing these species, Field (1989) used only 2 temperature levels, so differences in the effects of temperature are unclear, but she used 5 salinity levels. She concluded that at low salinities, a higher proportion of $M$. adina larvae survived than did $M$. mercenaria larvae; however, $M$. mercenaria developed faster at all salinities than did $M$. adina. Trigg et al. (1989) compared survival of adult [>60 $\mathrm{mm}$ carapace width $(\mathrm{CW})] \mathrm{M}$. adina and $M$. mercenaria at 4 temperatures and 4 salinities. They found that adult $M$. adina have a greater ability to tolerate combinations of low temperatures and low salinities, whereas adult $M$. mercenaria are better able to tolerate combinations of high temperatures and high salinities.

Understanding the physiology of postsettlement juvenile Menippe (those $\leq 10 \mathrm{~mm} \mathrm{CW}$ ) is important because crabs may remain in this size class for a full year (Tweedale et al. 1993) and therefore experience the annual range of temperature and salinity. Brown et al. (1992) studied the influence that these factors had on the survival and molting of postsettlement juvenile $M$. mercenaria in the laboratory. The present study examined the effects of temperature and salinity on both $M$. adina and $M$. mercenaria postsettlement juveniles over 2 years, allowing us to compare the responses between the 2 species and between years within a species. Our work promotes further understanding of the ecological differences between these species and of how these differences may be related to evolution within the genus.

\section{MATERIALS AND METHODS}

Menippe adina juveniles $\leq 10 \mathrm{~mm}$ CW were obtained from Mississippi Sound, Mississippi, during September $1990(n=269)$ and October $1991(n=415)$. Crabs were collected from mesh bags of oyster shell that had been suspended subtidally from channel markers. Juvenile
M. mercenaria were collected from Tampa Bay, Florida, during October 1989 ( $\mathrm{n}=304$ ) and June 1991 ( $n=271$ ), from the outside of commercial stone crab traps. Size of the juveniles ranged from 1.7 to $10.4 \mathrm{~mm}$ $\mathrm{CW}_{\text {; }}$ at least $90 \%$ of juveniles from each data set were between 2.3 and $9.4 \mathrm{~mm} \mathrm{CW}$.

In the laboratory, juveniles were held for $42 \mathrm{~d}$ in a factorial array of either 7 or 8 temperatures 15 to $35^{\circ} \mathrm{C}$, or 5 to $40^{\circ} \mathrm{C}, 5^{\circ} \mathrm{C}$ increments) and 7 salinities (10 to $40 \%$, $5 \%$ increments). These treatments were selected to include the range of conditions that juveniles would experience in their natural environment. For each treatment, 5 to 10 crabs were held separately in 100 to $150 \mathrm{ml}$ of artificial seawater, in either refrigerated incubators $\left(5\right.$ to $20^{\circ} \mathrm{C}$ and $40^{\circ} \mathrm{C}$ treatments) or temperature-controlled water baths (20 to $35^{\circ} \mathrm{C}$ treatments). Crabs were first acclimated to the experimental temperatures at a rate of $2^{\circ} \mathrm{C}$ per day, then acclimated to the experimental salinities at a rate of $2 \%$ every 2 to $3 \mathrm{~h}$. Each day of both the acclimation and experimental periods, juveniles were checked for molting activity or mortality; except for the days of salinity acclimation, crabs were fed minced conch every other day and placed in clean water of the appropriate temperature and salinity on the alternate day. Temperature was recorded daily and salinity was measured during the water change. The mean temperatures and salinities measured during the experiments varied no more than $0.4{ }^{\circ} \mathrm{C}$ and $0.7 \%$, respectively, from the predetermined experimental values

For each species, the proportion of juveniles molting during the experimental period (molting) and the proportion of juveniles surviving to the end of the experimental period (survival) were compared between years using the $\mathrm{R} \times \mathrm{C}$ G-test of independence (Sokal $\&$ Rohlf 1981). Because we found significant differences between years in both molting ( $p<0.001)$ and survival ( $\mathrm{p}<0.001$ ) for Menippe adina, each data set was treated separately. We found no significant difference in molting or in survival between the 2 years for $M$. mercenaria; therefore, we pooled the data sets for all analyses. No juveniles of either species that were held in $40^{\circ} \mathrm{C}$ water survived beyond the acclimation period; thus, the temperature range for all analyses was 5 to $35^{\circ} \mathrm{C}$

For each data set (1990 Menippe adina, 1991 $M$. adina, and $M$. mercenarial, the percentage of juveniles that survived in each treatment was squareroot transformed and fitted to a response-surface regression (SAS Institute, Inc. 1985). The effects of temperature $(T)$ and salinity $(S)$ on response $(R$, molting or survival) were analyzed using the nonparametric 3-way log-linear model (3-way G-test; Sokal \& Rohlf 1981). Step I of this test determined if a 3 -factor 
interaction existed among $T, S$ and $R_{i}$ if a significant $G$-value $(p \leq 0.025)$ resulted from this step, the $R \times C$ $G$-test was performed between pairs of factors $(T \times R$, $S \times R$ ) at each level of the third factor. Each $\mathrm{R} \times \mathrm{C} G$-test was followed by the simultaneous test procedure for homogeneity of frequencies (STP; Sokal \& Rohlf 1981) to determine at which treatments differences in response occurred. If step I of the 3-way G-test was not significant, we proceeded to step II, which tested for independent interactions between $T$ and $R$ and between $S$ and $R$. For each pair of factors found to have a significant 2 -factor interaction ( $p \leq 0.025$ ) in step II, we performed the STP over pooled values of the third factor to further define $T$ and $S$ effects. Steps III and IV of the 3-way G-test were not necessary for any of our analyses. Survival interval, defined as the proportion of the experimental period during which a crab remained alive, was calculated for each treatment with $100 \%$ mortality. The effect of $T$ or $S$ on mean survival interval was analyzed using the $\mathrm{R} \times \mathrm{C} G$-test and the STP.

We compared molting, survival, and mean survival interval of Menippe mercenaria to that of $1990 \mathrm{M}$. adina; because both overall survival and molting of $1991 M$. adina were significantly lower than that of either $1990 M$. adina or $M$. mercenaria, no further comparisons were made using the $1991 \mathrm{M}$. adina data set. Three-way $G$-tests were performed using the factors $T$, $R$, and species ( $M$ ) at each $S$ and using the factors $S, R$, and $M$ at each $T$. In this case, a nonsignificant result at step I determined that no 3-factor interaction existed and therefore that the effect of $T$ or of $S$ on $R$ did not differ between the species. At step II, 2-factor interactions were not tested between $T$ or $S$ and $M$ because these factors were all fixed by the experiment; 2 -factor interactions were also not examined between $T$ or $S$ and $R$ because we had already performed these tests for each species separately and were not interested in the effects of $T$ and $S$ on both species combined. The remaining test at step II, between $M$ and $R$, determined whether a response differed between $M$. adina and $M$. mercenaria at each $T$ or $S$ level. When a significant difference was found, we performed $\mathrm{R} \times \mathrm{C}$ G-tests between $M$ and $R$ at each temperature-salinity combination that was included in that $T$ or $S$ level. For each treatment in which all juveniles of both species died we compared mean survival intervals between species using the $\mathrm{R} \times \mathrm{C}$ G-test.

\section{RESULTS}

\section{Molting}

For 1990 Menippe adina, the highest proportion of juveniles $(83 \%)$ molted in water of $25^{\circ} \mathrm{C}, 20 \%$ and $30{ }^{\circ} \mathrm{C}, 15 \%$; for $1991 \mathrm{M}$. adina, the highest proportion of juveniles $(78 \%)$ molted in water of $30^{\circ} \mathrm{C}, 20 \%$. In both data sets, the only significant interactions were the 2 -factor interactions between $T$ and molting $(p<0.001)$. A number of crabs molted in water of 20 to $35^{\circ} \mathrm{C}$, but few or no crabs molted in water of 5 to $15^{\circ} \mathrm{C}$ (Table 1).

The percentage of Menippe mercenaria that molted was highest $(83 \%)$ in water of $20^{\circ} \mathrm{C}, 25 \%$. In this species too, $T$, but not $S$, significantly affected molting $(p<0.001)$. A moderate-to-high percentage of juveniles molted in 20 to $30^{\circ} \mathrm{C}$ water, a low percentage of juveniles molted in 15 and $35^{\circ} \mathrm{C}$ water, and no juveniles molted in 5 to $10^{\circ} \mathrm{C}$ water (Table 1 ).

When the species were compared at each $S$ level, the $G$-values for the 3-factor interactions among $T, M$, and molting were not significant. The absence of 3 -factor interactions indicates that neither the magnitude nor the direction of the effect of $T$ differed between the species. In both species, molting was very low or nonexistent from 5 to $15^{\circ} \mathrm{C}$, increased from 20 to $30^{\circ} \mathrm{C}$, then decreased at $35^{\circ} \mathrm{C}$ (Fig. 1).

Table 1. Menippe spp. Homogeneous sets of temperature levels for the proportion of postsettlement juveniles that molted (pooled salinities). Temperatures are ordered, left to right, from lowest to highest percentage of crabs that molted (shown in parentheses). Underlined groups of temperatures did not have significantly different molt frequencies (simultaneous test procedure for homogeneity of frequencies)

\begin{tabular}{|c|c|c|c|c|c|c|c|}
\hline \multirow{2}{*}{$\frac{\text { Data set }}{\text { M. adina, } 1990^{\circ}}$} & \multicolumn{7}{|c|}{ Temperature $\left({ }^{\circ} \mathrm{C}\right), \%$ of crabs molted } \\
\hline & $5(0)$ & $10(2)$ & $15(3)$ & $20(27)$ & $35(37)$ & $25(47)$ & $30(55)$ \\
\hline M. adina, $1991^{\circ}$ & $5(0)$ & $10(0)$ & $15(1)$ & $35 \quad(6)$ & $20(21)$ & $25(23)$ & $30(36)$ \\
\hline M. mercenaria, 1989 and 1991, combined ${ }^{c}$ & $5(0)$ & $10(0)$ & $15(6)$ & $35(18)$ & $20(30)$ & $25(44)$ & $30(49)$ \\
\hline
\end{tabular}




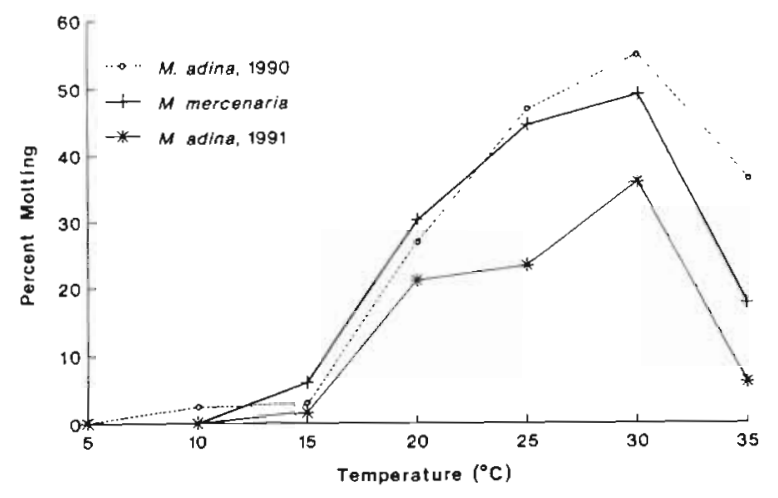

Fig. 1. Menippe spp. Percentage of postsettlement juveniles that molted at each temperature level tested (pooled salinities)

\section{Survival}

One hundred percent of Menippe adina survived in the following treatments: $1990-15^{\circ} \mathrm{C}$ and $20,25,35$ or $40 \% ; 20^{\circ} \mathrm{C}$ and 15 to $35 \%$; $30^{\circ} \mathrm{C}$ and 30 or $35 \%$; $1991-20^{\circ} \mathrm{C}$ and $25 \%$. Although overall survival was lower for $1991 \mathrm{M}$. adina than for $1990 \mathrm{M}$. adina, response-surface regressions predicted optimal survival at similar conditions for each data set; highest survival of $1990 \mathrm{M}$. adina was predicted at $23^{\circ} \mathrm{C}, 33 \%$ $\left(\mathrm{r}^{2}=0.74, \mathrm{p}<0.001\right)$, and highest survival of $1991 \mathrm{M}$. adina was predicted at $21{ }^{\circ} \mathrm{C}, 33 \%\left(\mathrm{r}^{2}=0.64, p<0.001\right)$. For $1990 \mathrm{M}$. adina, a significant 3-factor interaction existed among $T, S$, and survival ( $p<0.001$ ). High proportions of juveniles survived in water of 15 to $30^{\circ} \mathrm{C}$ and 20 to $40 \%$ (Table 2); at $T$ levels near the optimum temperature, survival was very high over a wide range of $S$, and at high $T$ levels, survival was highest at high $S$. For $1991 M$. adina, $T$ and $S$ affected survival independently (each factor: $\mathrm{p}<0.001$ ). Survival was low at extreme $T$ levels $\left(5\right.$ and $35^{\circ} \mathrm{C}$ ) but generally increased as $T$ approached the optimum; survival at all salinities above $20 \%$ was relatively high (Table 2 ).

Survival of Menippe mercenaria was $100 \%$ in water of $15^{\circ} \mathrm{C}$ and 25 or $35 \% ; 20^{\circ} \mathrm{C}$ and 30 to $40 \%$; $25^{\circ} \mathrm{C}$ and $35 \%$. Optimal survival of juveniles was predicted by the response-surface regression at $22^{\circ} \mathrm{C}, 32 \%\left(\mathrm{r}^{2}=\right.$ $0.81, p<0.001$ ). Independently, $T$ and $S$ significantly affected survival (each factor: $p<0.001$ ); comparatively high survival was observed at the 15 to $30^{\circ} \mathrm{C}$ levels and at the 20 to $40 \%$ levels (Table 2).

When Menippe mercenaria survival was compared to $1990 \mathrm{M}$. adina survival, no significant 3 -factor interactions were found among $T, M$, and survival or among $S, M$, and survival. Again, the lack of interactions indicates that the patterns of the $T$ and $S$ responses were the same for both species. Two-factor interactions between $M$ and survival were significant at the $20^{\circ} \mathrm{C}$
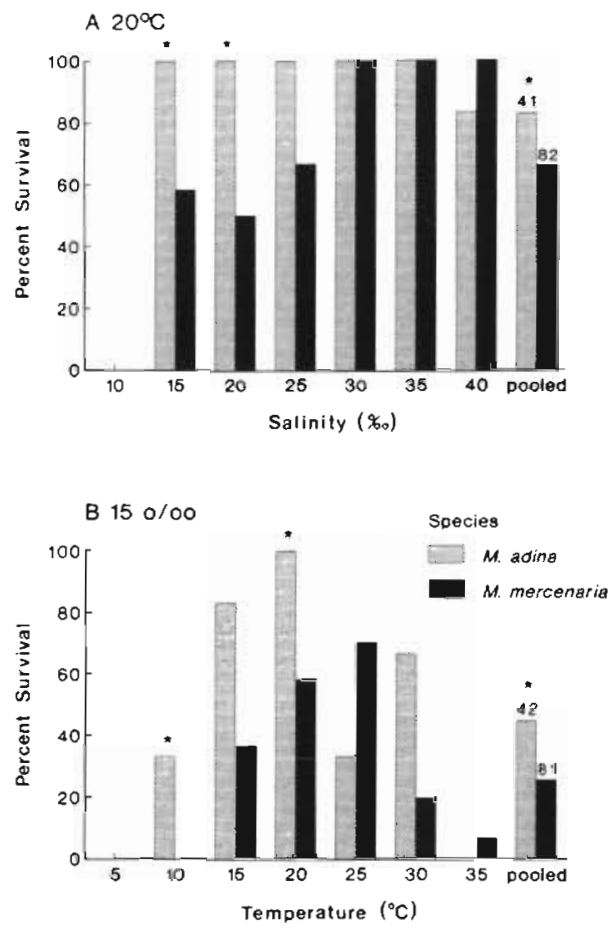

Fig. 2. Menippe spp. Percentage of postsettlement juveniles that survived at factor levels where significant differences between species were found. (A) $20^{\circ} \mathrm{C}$ (B) $15 \%$. 'Treatments where survival of $M$. adina was significantly greater than that of $M$. mercenaria (p ranged from 0.018 to 0.035 ). Sample size ranges for each cell: $M$. adina, 1990: 5 to $7_{i} M$. mercenaria, 1989 and 1991 combined: 10 to 15 . Pooled $\mathrm{n}$ is shown above the bar for each species

$(\mathrm{p}=0.015)$ and $15 \%(\mathrm{p}=0.012)$ levels (Fig. 2), and in both cases survival of $M$. adina was higher than survival of $M$. mercenaria.

\section{Survival interval}

For 1990 Menippe adina, mean survival interval at $5^{\circ} \mathrm{C}$ generally increased significantly with each $S$ increment; at $10 \%$, mean survival interval was significantly shorter at $5^{\circ} \mathrm{C}$ than at other $T$ values and increased with $\mathrm{T}$ through $30^{\circ} \mathrm{C}$ (Fig. 3A). Shortest mean survival interval of $1991 \mathrm{M}$. adina was at combinations of extreme $I$ ( 5 or $35^{\circ} \mathrm{C}$ ) and low $S(10 \%)$ (Fig. 3B). Mean survival interval of $M$. mercenaria held at combinations of low $S(10$ to $15 \%$ ) and either low or extremely high $T\left(5,10\right.$, and $\left.35^{\circ} \mathrm{C}\right)$ was significantly shorter than mean survival interval of juveniles held at low levels of one factor and intermediate or high levels of the alternate factor (Fig. 3C).

No juveniles of either 1990 Menippe adina or $M$. mercenaria survived to the end of the experiment at any treatment including $10 \%$ or at the treatments of $5{ }^{\circ} \mathrm{C}, 15$ to $30 \%$. Mean survival interval differed sig- 
Table 2. Menippe spp. Homogeneous sets of treatments for the proportion of postsettlement juveniles that survived. Treatments are ordered, left to right, from lowest to highest percentage of crabs that survived (shown in parentheses). Underlined groups of treatments did not have significantly different survival (simultaneous test procedure for homogeneity of frequencies)

\begin{tabular}{|c|c|c|c|c|c|c|c|}
\hline \multirow{2}{*}{$\begin{array}{l}\text { M. adina } 1990^{a} \\
\text { Salinity }(\% \infty) \\
\quad 10\end{array}$} & \multicolumn{7}{|c|}{ Temperature $\left({ }^{\circ} \mathrm{C}\right), \%$ survival } \\
\hline & $5 \quad(0)$ & $10 \quad(0)$ & $15(0)$ & $20 \quad(0)$ & 25 & $(0)$ & 35 \\
\hline 15 & $5 \quad(0)$ & $35 \quad(0)$ & $10(33)$ & $25(33)$ & $30 \quad(67)$ & $15(83)$ & $20(100)$ \\
\hline 20 & $5 \quad(0)$ & $10(17)$ & $35(50)$ & $30(67)$ & $25 \quad(83)$ & $15(100)$ & $20(100)$ \\
\hline 25 & $5 \quad(0)$ & $35(50)$ & $10(67)$ & $25(67)$ & $30 \quad(83)$ & $15(100)$ & $20(100)$ \\
\hline 30 & $5 \quad(0)$ & $10(17)$ & $25(50)$ & $15(67)$ & $35 \quad(67)$ & $20(100)$ & $30(100)$ \\
\hline 35 & $5(17)$ & $10(50)$ & $35(50)$ & $25(67)$ & $15(100)$ & $20(100)$ & $30(100)$ \\
\hline 40 & $5(20)$ & $10(67)$ & $25(67)$ & $35(67)$ & $20 \quad(83)$ & $30 \quad(83)$ & $15(100)$ \\
\hline Temperature $\left({ }^{\circ} \mathrm{C}\right)$ & & & Sali & $\%$ ), \% sur & & & \\
\hline 5 & $10(0)$ & $15 \quad(0)$ & $20 \quad(0)$ & $25 \quad(0)$ & (0) & $35 \quad(17)$ & $40 \quad(20)$ \\
\hline 10 & $10(0)$ & $20\{17\}$ & $30 \quad(17)$ & $15 \quad(33)$ & $35 \quad(50)$ & $25 \quad(67)$ & $40 \quad(67)$ \\
\hline 15 & $10(0)$ & $30(67)$ & $15 \quad(83)$ & $20(100)$ & $25(100)$ & $35(100)$ & $40(100)$ \\
\hline 20 & $10(0)$ & $40(83)$ & $15(100)$ & $20(100)$ & $25(100)$ & $30(100)$ & $35(100)$ \\
\hline 25 & $10(0)$ & $15(33)$ & $30 \quad(50)$ & $25 \quad(67)$ & $35 \quad(67)$ & $40 \quad(67)$ & $20 \quad(83)$ \\
\hline 30 & $10(0)$ & $15(67)$ & $20 \quad(67)$ & 25 (83) & $40 \quad(83)$ & $30(100)$ & $35(100)$ \\
\hline 35 & $10(0)$ & $15 \quad(0)$ & $20 \quad(50)$ & $25 \quad(50)$ & $(50)$ & $30 \quad(67)$ & $40 \quad(67)$ \\
\hline
\end{tabular}

M. adina 1991, pooled values ${ }^{\mathrm{b}}$

Temperature $\left({ }^{\circ} \mathrm{C}\right), \%$ survival

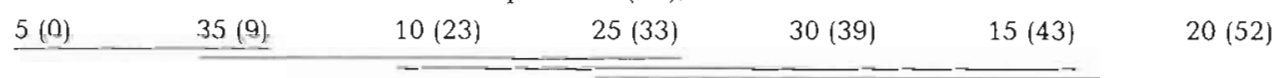

Salinity (\%), \% survival

$\begin{array}{llllll}10(0) & 15 \underline{(9)} & 20(26) & 30(37) & 35(38) & 40(42)\end{array}$

M. mercenaria 1989 and 1991 , pooled values ${ }^{c}$

Temperature $\left({ }^{\circ} \mathrm{C}\right), \%$ survival

$\underline{5(0)} \quad \underline{35(28)} \quad 10(29) \quad 30(49) \quad 20(67) \quad 15(69) \quad 25(71)$

Salinity $(\%), \%$ survival

\begin{tabular}{|c|c|c|c|c|c|c|}
\hline $10(2)$ & $15(26)$ & $20(40)$ & $40(51)$ & $25(59)$ & $35(61)$ & $30(62)$ \\
\hline
\end{tabular}

${ }^{a} \mathrm{n}$ ranged from 5 to $7_{i}{ }^{\mathrm{b}} \mathrm{n}$ ranged from 62 to $69(\vec{x}=66) ;{ }^{\mathrm{c}} \mathrm{n}$ ranged from 76 to $105(\bar{x}=84)$ 

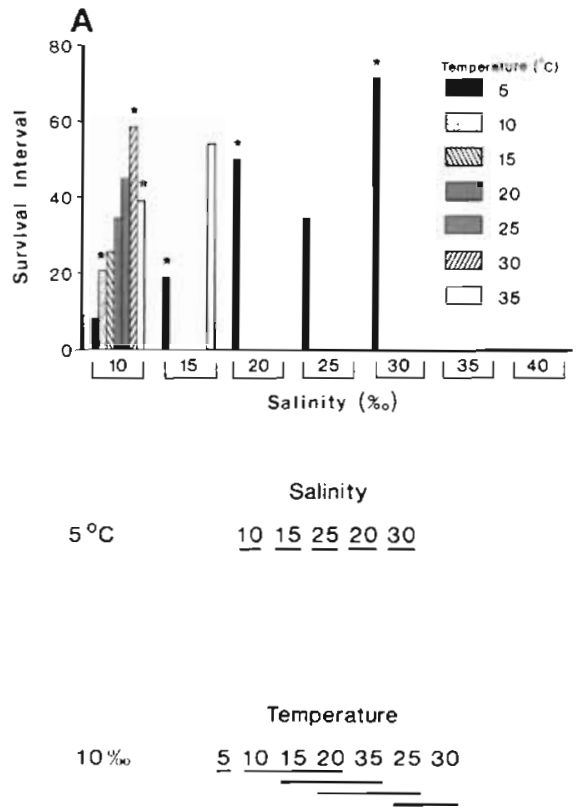

B

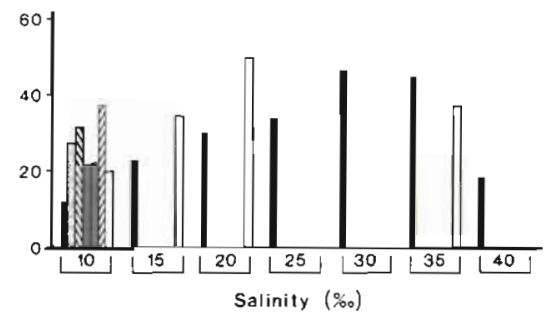

Salinity

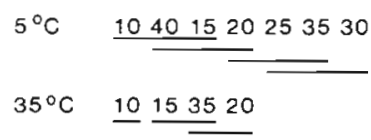

Temperature

$10 \%$

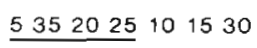

\section{C}

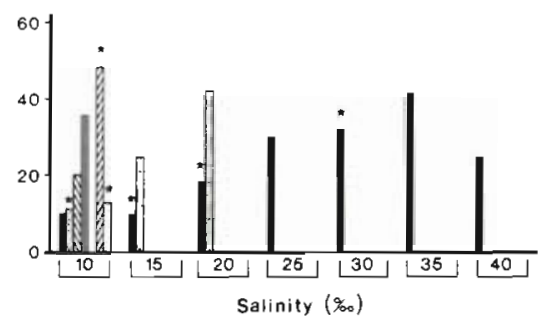

Salinity

$5^{\circ} \mathrm{C} \quad \underline{1510} 2040253035$

$10^{\circ} \mathrm{C} \quad$ 10 $15 \underline{20}$

Temperature

$10 \%$

51035152030

Fig. 3. Menippe spp. Mean survival interval (percentage of the experimental period that crabs lived) of postsettlement juveniles at treatments with 100\% mortality. (A) M. adina, 1990. (B) M. adina, 1991. (C) M. mercenaria, 1989 and 1991 combined. Groupings below histograms show homogeneous sets of temperatures and salinities for each data set. Treatments are ordered, left to right, from lowest to highest mean survival interval. Underlined groups of treatments did not have significantly different mean survival intervals (simultaneous test procedure for homogeneity of frequencies). "Treatments where mean survival interval of $M$. adina was significantly greater than that of $M$. mercenaria ( $p$ ranged from $<0.001$ to 0.009 )

nificantly between species at several of these treatments (see asterisks in Fig. 3); at each treatment, mean survival interval of $M$. adina was significantly longer than mean survival interval of $M$. mercenaria. In general, treatments that included $10^{\circ} \mathrm{C}$ and low or moderate $S(10$ to $20 \%$ ) were lethal to $M$. mercenaria, but only $10^{\circ} \mathrm{C}, 10 \%$ was lethal to $M$. adina (Fig. 3). In both species, juveniles held in $10 \%$ water survived longest at $30^{\circ} \mathrm{C}$, and juveniles held in $5^{\circ} \mathrm{C}$ water survived longest at 30 to $35 \%$.

\section{DISCUSSION}

Differences in overall survival between Menippe adina juveniles collected in 1990 and in 1991 may have been the result of unusual hydrological conditions in Mississippi Sound in 1991. During May of that year, salinities declined to less than $10 \%$ and did not increase until mid-July (Gulf Coast Research Laboratory, Ocean Springs, MS, USA, unpubl. data). No ovigerous females were observed in the Sound until August (H. M. Perry pers. comm.), so virtually all of the juveniles in our study would have hatched from eggs spawned within 1 mo after salinities began to increase. The low salinity during that period may have negatively affected the gravid or ovigerous females, the embryos, or the larvae. This result supports the idea that annual differences in temperatures and salinities can greatly influence overall survival within a species. Nevertheless, the patterns of the temperature and salinity effects were similar and the optimal conditions predicted for survival were nearly identical for the 2 groups, indicating that the effects of temperature and salinity are constant from year to year.

The similarity between Menippe adina and $M$. mercenaria in the relatively low temperature predicted for optimal survival is not surprising; the operation of natural selection should be such that each species would have evolved so that survival was highest when juveniles were most abundant. In both Mississippi Sound and Tampa Bay, highest numbers of postsettlement juveniles have been collected when temperatures are decreasing from summer highs of approximately $30^{\circ} \mathrm{C}$ to values around $25^{\circ} \mathrm{C}$ (Stuck \& Perry 1992, Bert unpubl. data). The low temperature values for optimal survival may also be based on physiology. The hemocyanin-oxygen transport system in adult $M$. mercenaria works most efficiently at $15^{\circ} \mathrm{C}$, and an increase to $25^{\circ} \mathrm{C}$ decreases oxygenation to about $50 \%$ (Mauro \& Mangum 1982).

The patterns of the effects of temperature and salinity on molting were similar for both Menippe adina and $M$. mercenaria; the proportion of juveniles that 
molted was very low in 5 to $15^{\circ} \mathrm{C}$ water, increased with water temperature to $30^{\circ} \mathrm{C}$, and then decreased in $35^{\circ} \mathrm{C}$ water. Although the effects of temperature on molt frequency of juveniles did not differ between species, annual growth rates in nature may differ between the 2 populations we sampled because mean high and low temperatures and the lengths of the seasons vary latitudinally. In Tampa Bay, water temperatures typically are $30^{\circ} \mathrm{C}$ or higher during July and August and are $20^{\circ} \mathrm{C}$ or lower from December through February (Fig. 4). In Mississippi Sound, water temperatures may reach $30^{\circ} \mathrm{C}$ only during September, if at all, and typically are less than $20^{\circ} \mathrm{C}$ from December through April (Fig. 4). Because molt frequency declines as temperature decreases below $30^{\circ} \mathrm{C}$ and virtually ceases below $20^{\circ} \mathrm{C}$, juveniles from the population farther south may have a longer annual growth period.

High proportions of juveniles of both species survived in water of 15 to $30^{\circ} \mathrm{C}$ and 20 to $40 \%$; nevertheless, we found significant differences between Menippe mercenaria and $1990 \mathrm{M}$. adina in the proportion of juveniles that survived at specific temperature and salinity levels. Both high and low levels of temperature and salinity influenced juvenile survival, but we saw the strongest evidence of a difference between species near the lower ends of their tolerance ranges. Juveniles of neither species showed a significant decrease in survival with increased salinity, but the upper temperature limit for survival was between 35 and $40^{\circ} \mathrm{C}$ for both $M$. mercenaria and $M$. adina. Because water temperatures rarely exceed $35^{\circ} \mathrm{C}$ in most parts of the species range, juveniles would seldom encounter temperatures too high for survival. Alternatively, a significantly higher proportion of $M$. adina survived than did $M$. mercenaria at several treatments that included both low salinities and low to intermediate temperatures. In addition, $M$. adina survived in $5^{\circ} \mathrm{C}$ water if salinity was high, but $M$. mercenaria did not. A low-salinity threshold for both species was evident between 10 and $15 \%$; however, survival intervals calculated from our data showed that when held in water of $30^{\circ} \mathrm{C}, M$. adina survived approximately $4 \mathrm{wk}$ at $10 \%$, significantly longer than $M$. mercenaria survived. Thus, $M$. adina appear to tolerate a broader range of naturally occurring temperatures and salinities than do $M$. mercenaria, allowing them to better survive variation on both a spatial and a temporal scale.

Tolerance limits of a species in the early life stages may be critical in determining its distribution. For most organisms, tolerance to environmental extremes increases with ontogeny (Kinne 1970, 1971), and this appears to be true for both species of Menippe. The limits of temperature tolerance for $M$. adina larvae are

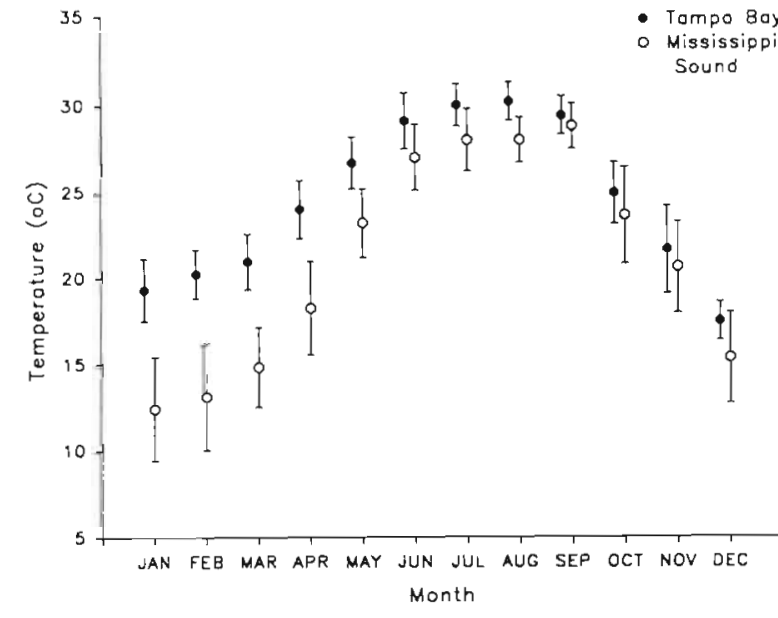

Fig. 4. Mean monthly temperatures ( $\pm \mathrm{SD}$ ): Mississippi Sound, Mississippi, USA, December 1973 to February 1992 (Gulf Coast Research Laboratory, Ocean Springs, MS, unpubl. data); Tampa Bay, Florida, USA, May 1988 to December 1992 (Hillsborough County Environmental Protection Commission, Tampa, FL, unpubl. data)

unclear from previous work, but low-temperature tolerances of larvae and postsettlement juveniles may define the northern limit of the species' range for M. mercenaria (Brown et al. 1992). Tolerance to salinity, on the other hand, may help determine the location of a population in relation to the coast (see e.g. Mills \& Fish 1980, Steele \& Steele 1991). Because M. adina juveniles have a greater tolerance to low salinities, this species may be able to inhabit nearshore areas that are not tolerated by $M$. mercenaria in early stages of the life cycle.

Differences in temperature or salinity tolerances between 2 populations may be due to 3 reasons (Kinne 1962): acclimatization, irreversible non-genetic compensation, or genetic differences. We acclimated the juveniles to the test temperatures and salinities, thus eliminating any acclimatization that had already taken place. Because they had been spawned no more than 2 mo before collection, the juveniles used in our comparative analyses had experienced very little variation, either as eggs or as larvae, from the temperatures and salinities at which they were collected. These temperatures and salinities were similar for both 1990 Menippe adina and $M$. mercenaria, so non-genetic compensation was also unlikely. Thus, the differences we see must have a genetic basis. An important question remains: Are these differences speciesspecific, or are they the result of heritable, local adaptation? Examples can be found of genetic differences in the temperature responses of organisms among populations both within and between species, even over relatively short latitudinal distances 
(2 to $5^{\circ}$ ). Populations of Crassostrea virginica from Massachusetts/Long Island and New Jersey/Virginia required different temperatures for spawning even after a 2 yr acclimation (Loosanoff \& Nomejko 1951). Differences in survival and growth of Ophryotrocha costlowi and $O$. macrovifera held at various temperatures persisted for 10 generations (Levinton 1983).

From our data we cannot determine whether the different temperature tolerances of Menippe adina and $M$. mercenaria are due to genetic differences between species or to adaptation to local conditions, but a combination seems probable. When viewed in conjunction with field studies, the differences that we observed in salinity tolerances seem to be speciesspecific, but the differences in response to temperature may be a combination of species-specific differences and within-species adaptation. Throughout the species' ranges, $M$. adina is found in lower salinity waters than is $M$. mercenaria (see Sullivan 1979, Bert et al. 1986, Landry 1992, Stuck \& Perry 1992); in the zone of hybridization, $M$. adina is more common nearshore where salinity is lower and more variable, but both species occur offshore (Wilber 1992, Bert unpubl. data). Furthermore, despite the similar salinity conditions to which the juveniles used in our species comparison were exposed prior to collection, juvenile $M$. adina exhibited higher survival in low salinity water, particularly in low-salinity/low-temperature combinations. In contrast, the temperature ranges experienced overall by the 2 species in nature are similar because the latitudinal range of $M$. mercenaria spans that of $M$. adina (Williams \& Felder 1986). Still, our juvenile $M$. adina had a greater ability to survive in low temperatures. As with the lengths of the growth and reproductive seasons, which are presumed to be strongly influenced by temperature (Bert et al. 1986, Brown et al. 1992) and vary inversely with latitude, this tolerance may be the result of adaptation to conditions at the location of collection. Nevertheless, some species-specific adaptation toward an overall broader temperature tolerance in $M$. adina is likely, because the estuarine waters occupied by $M$. adina typically exhibit greater temperature fluctuations than do more oceanic waters.

A total or partial species-specific difference in tolerances to temperature and salinity supports the scenario for the divergence of Menippe mercenaria and M. adina proposed by Bert (1986). She suggested that the terminal Miocene glaciation caused sufficient reduction in the range of the ancestral species and alteration of major oceanic current flow as to cause a decrease in gene flow between populations in the eastern and western Gulf of Mexico and Caribbean Sea. While the 2 populations were separated, each would have inhabited regions with different physical attributes; adaptations of each population to its environment may have resulted in a divergence in tolerances to environmental factors. After subsequent range expansion and secondary contact by the populations, each newly diverged form would have remained essentially in different types of environments: $M$. mercenaria would have occupied areas with more stable temperatures and marine salinities, and $M$. adina would have occurred in areas with larger annual variations in temperature and salinity. The distributional patterns of the species and the partial habitat partitioning in the zone of hybridization that we see today suggest that selection is continuing to promote those physiological differences developed initially in allopatry.

Acknowledgements. The authors thank D. Bartolacci, C Mayo, T. Orsoy, J. Risser, D. Romero, and W. Tweedale for laboratory assistance. We also thank K. McCarthy, H. Perry, and K. Stuck for field support. We appreciate data received from the Gulf Coast Research Laboratory, Ocean Springs, MS, USA, via H. Perry, and from Hillsborough County Environmental Protection Commission, Tampa, FL, USA, via R. Boler. This research was funded by grants from the Department of Commerce, National Oceanographic and Atmospheric Administration (P.L. 99-659 [Project 2-IJ-2]) and from the Florida Sea Grant College Program (Project R/LR-B24), and by the Florida Department of Natural Resources, Florida Marine Research Institute.

\section{LITERATURE CITED}

Antonopoulou, E., Emson, R. (1989). The combined effects of temperature and salinity on survival, moulting and metamorphosis of the larval stages of three species of palaemonid prawns. In: Ryland, J. S., Tyler, P. A. (eds.) Reproduction, genetics and distribution of marine organisms. Olsen and Olsen, Fredensborg, p. 339-347

Baltz, D. M., Horst, J. W. (1992). Depth and substrate selection, sex ratio, and size distribution in an unexploited stone crab (Menippe adina) population in Barataria Bay, Louisiana. In: Bert, T. M. (ed.) Proceedings of a symposium on stone crab (genus Menippe) biology and fisheries. Fla mar. Res. Publs 50: 74-81

Bert, T M. (1986). Speciation in western Atlantic stone crabs (genus Menippe): the role of geological processes and climatic events in the formation and distribution of species Mar. Biol. 93: 157-170

Bert, T M., Harrison, R. G. (1988). Hybridization in western Atlantic stone crabs (genus Menippe): evolutionary history and ecological context influence species interactions. Evolution 42: 528-544

Bert, T. M., Tilmant, J., Dodrill, J, Davis, G. E. (1986). Aspects of the population dynamics and biology of the stone crab (Menippe mercenaria) in Everglades and Biscayne National Parks as determined by trapping. U.S. Natl Park Serv., S. Fla Res. Cent. Rep. SFRC-86/04, Everglades National Park, Homestead, FL

Brown, S. D., Bert, T M., Tweedale, W. A., Torres, J. J., Lindberg, W. J. (1992). The effects of temperature and salinity on survival and growth of early life stage Florida stone crabs (Menippe mercenaria). J. exp. mar. Biol. Ecol. 157: $115-136$ 
Field, C. J. (1989). Effects of salinity and temperature on survival and development time of the larvae of stone crabs, Menippe mercenaria (Say, 1818) and Menippe adina Williams and Felder, 1986 (Decapoda: Brachyura: Xanthidae). M.Sc thesis, Louisiana State University, Baton Rouge

Hochachka, P. W., Somero, G. N. (1984). Biochemical adaptation. Princeton University Press, Princeton

Kinne, O. (1962). Irreversible nongenetic adaptation. Comp. Biochem. Physiol. 5: 265-282

Kinne, O. (1970). Temperature. In: Kinne, O. (ed.) Marine ecology, Vol. I, Part 1. Wiley-Interscience, New York, p. $321-514$

Kinne, O. (1971). Salinity. In: Kinne, O. (ed.) Marine ecology, Vol. I, Part 2. Wiley-Interscience, New York, p. 683-995

Landry, A. M. Jr (1992). Characterization and fishery development potential of Galveston Bay, Texas, stone crab (Menippe adina) stocks. In: Bert, T. M. (ed.) Proceedings of a symposium on stone crab (genus Menippe) biology and fisheries. Fla mar. Res. Publs 50:67-73

Levinton, J. S. (1983). The latitudinal compensation hypothesis: growth data and a model of latitudinal growth differentiation based upon energy budgets. I. Interspecific comparison of Ophryotrocha (Polychaeta: Dorvilleidae). Biol. Bull. 165: 686-698

Loosanoff, V. L., Nomejko, C. A. (1951). Existence of physiologically-different races of oysters, Crassostrea virginica. Biol. Bull. 101: 151-156

Mangum, C. P. (1963). Studies on speciation in maldanid polychaetes of the North American Atlantic coast. III. Intraspecific and interspecific divergence in oxygen consumption. Comp. Biochem. Physiol. 10: 335-349

Mauro, N. A., Mangum, C. P. (1982). The role of the blood in the temperature dependence of oxidative metabolism in decapod crustaceans. II. Interspecific adaptations to latitudinal change. J. exp. Zool. 219: 189-195

Mills, A., Fish, J. D. (1980). Effects of salinity and temperature on Corophium volutator and C. arenarium (Crustacea: Amphipoda), with particular reference to distribution. Mar. Biol. 58: 153-161

Ong, K. S., Costlow, J. D. Jr (1970). The effect of salinity and temperature on the larval development of the stone crab,

This article was submitted to the editor
Menippe mercenaria (Say), reared in the laboratory. Chesapeake Sci. 1. 168-177

Rodriguez, G. A. (1981). Osmoregulation and total serum protein of two species of penaeidean shrimps from the Pacific coast of Mexico. J. crust. Biol. 1: $392-400$

SAS Institute, Inc. (1985). SAS user's guide: statistics, Version 5 edn. SAS Institute, Inc., Cary, NC

Sokal, R. R., Rohlf, F. J. (1981). Biometry. W. H. Freeman and Co., San Francisco

Steele, D. H., Steele, V. J. (1991). Effects of salinity on the survival, growth rate, and reproductive output of Gammarus lawrencianus (Crustacea, Amphipoda). Mar. Ecol. Prog. Ser. 78: $49-56$

Stuck, K. C., Perry, H. M. (1992). Life history characteristics of Menippe adina in Mississippi coastal waters. In: Bert, $T$ M. (ed.) Proceedings of a symposium on stone crab (genus Menippe) biology and fisheries. Fla mar. Res. Publs 50: $82-98$

Sullivan, J. R. (1979). The stone crab, Menippe mercenaria, in the southwest Florida fishery. Fla mar. Res. Publs 36

Trigg, C., Perry, H., Henry, R. (1989). Salinity and metabolic adaptations of taxa of the genus Menippe in the Gulf of Mexico. Annual report to Mississippi-Alabama Sea Grant Consortium Project R/LR-21

Tweedale, W. A., Bert, T M., Brown, S. D. (1993). Growth of postsettlement juveniles of the Florida stone crab, Menippe mercenaria (Say) (Decapoda: Xanthidae). Bull. mar. Sci. 52

Watts, S. A., Scheibling, R. E., Marsh, A. G., McClintcock, J. B. (1982). Effect of temperature and salinity on larval development of sibling species of Echinaster (Echinodermata: Asteroidea) and their hybrids. Biol. Bull. 163: $348-354$

Wilber, D. H. (1992). Observations on the distribution and mating patterns of adult stone crabs (genus Menippe) on the northern gulf coast of Florida. In: Bert, T. M. (ed.) Proceedings of a symposium on stone crab (genus Menippej biology and fisheries. Fla mar. Res. Publs 50: $10-16$

Williams, A. B., Felder, D. L. (1986). Analysis of stone crabs: Menippe mercenaria (Say), restricted, and a previously unrecognized species described (Decapoda: Xanthidae). Proc. biol. Soc. Wash. 99: 517-543

Manuscript first received: September 14, 1992 Revised version accepted: May 12, 1993 